\title{
The Impact of Climate Change on a Residential Housing, in terms of Interior Thermal Comfort and Energy Consumption
}

\author{
Carlos Alberto Fuentes Pérez* \\ Autonomous University of Tamaulipas, México
}

Submission: October 15, 2018; Published: November 16, 2018

*Corresponding author: Carlos Alberto Fuentes Pérez, Autonomous University of Tamaulipas, México

\begin{abstract}
The residential housing should provide a comfortable indoor environment that should be reasonably assured regardless of the weather fluctuations from outside. The exterior climate together with the architectural design and materials of residential housing in a suburban area in the Municipality of Juarez, Nuevo León, Mexico and the construction system determined by the thermal performance and the ability to offer comfortable conditions to the user. Depending on the comfort zone and its temperature of the study with a model of hourly variation of the comfortable limits that would have thermal advantages, some of them related to the studies on climate adaptation in residential housing. To identify the effects of each constructive variable on environmental comfort or on the energy efficiency of residential housing in the Municipality of Juárez, Nuevo León. The research objective is to determine in the indoor environment the critical seasonal temperature oscillations in summer and winter of residential housing, establishing the user's comfort adaptability.
\end{abstract}

Keywords: Interior Environment; Thermal oscillations; Suburban residential housing

\section{Introduction}

One of the important points within residential housing, is the proper management of solar energy, materials and construction solutions, as basic elements of natural air conditioning, Sodoudi et al. [1]. In fact, for the experience in this field is very vast, since for a long-time ancient civilization use solar geometry and the thermophysical properties of building materials, in order to achieve environmental conditions appropriate to the interior. The thermal behavior is one of the most important variables to take into consideration in bioclimatic housing adaptability strategies. It basically refers to the conditions of the hygrothermal environment to the interior, but from the point of view of the relationship of the balance between the conditions of air temperature and relative humidity of a given place. Therefore, experts express that designers must work with nature to create climatically pleasing spaces for human activities, by Li [2].

The purpose of the research is to know the importance of the use of thermal behavior and environmental factors in accordance with the calorific energy gains of residential housing by observing and measuring what are the conditions of the degree of bioclimatic adaptability in Juárez Nuevo, León. In the understanding that to mitigate the displacement of heat inside the residential housing should be considered passive or natural climate system that is used. Traditional architectural typologies can play a crucial role in the contemporary environmental architectural framework, due to the numerous attempts developed in recent decades to adopt a model of passive housing and bioclimatic criteria in Mexico. According to a climate sensitive approach by Croitoru et al. [3], the interactive and adaptive relationship between constructions, the site and climate, it considers a basic rule to reduce the environmental impact and improve energy efficiency in the residences. In the last decades, this concept has extended to the preservation of the cultural identity of places. It can be deducted as a high level of adaptive, sustainable and functional performance from residential homes, as evidenced by the housing in the Municipality of Juárez, Nuevo León.

\section{Residential Housing Case Study}

The residential housing case study presents a tendency in relation to the orientation of $20^{\circ}$ to the East, arranged with NorthSouth orientation, caused by the layout. It presents in its entirety $1,000 \mathrm{M}^{2}$ of construction, on a 20-hectare plot of land in a rural suburban area of the Municipality of Juárez, Nuevo León. Mexico.

\section{Research Methodology}

Historical climate analysis of the Municipality of Juárez, Nuevo León. Mexico Determine the study area of residential housing and its thermal assessment Measurement tools.

\section{Historical climate analysis 1992 to 2017}

Regarding the environment of residential housing was determined by the weather assessment of the last 25 years, which 


\section{Civil Engineering Research Journal}

presents August with an average temperature of $30.47{ }^{\circ} \mathrm{C}$ and a relative humidity of $61.35 \%$, is the critical month in summer. The linear trend in the Municipality of Juárez, Nuevo León is $0.48{ }^{\circ} \mathrm{C}$. January presents a temperature of the historical climate analysis of the last 25 in the Municipality of Juárez, Nuevo León of 11.9 ${ }^{\circ} \mathrm{C}$ and a relative humidity of $76.78 \%$ being the critical month of winter, abroad Figure 1.

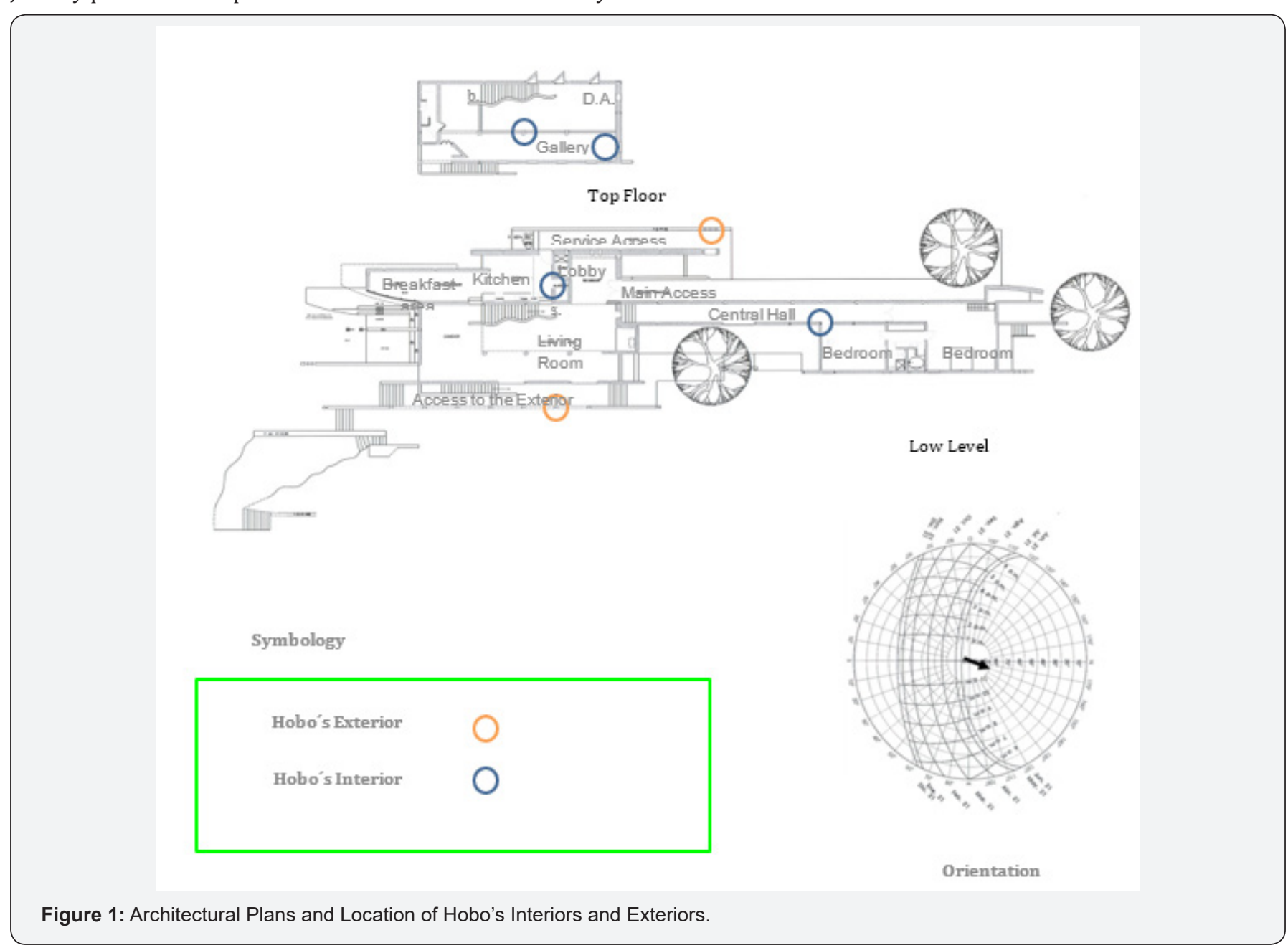

\section{Study area of residential housing}

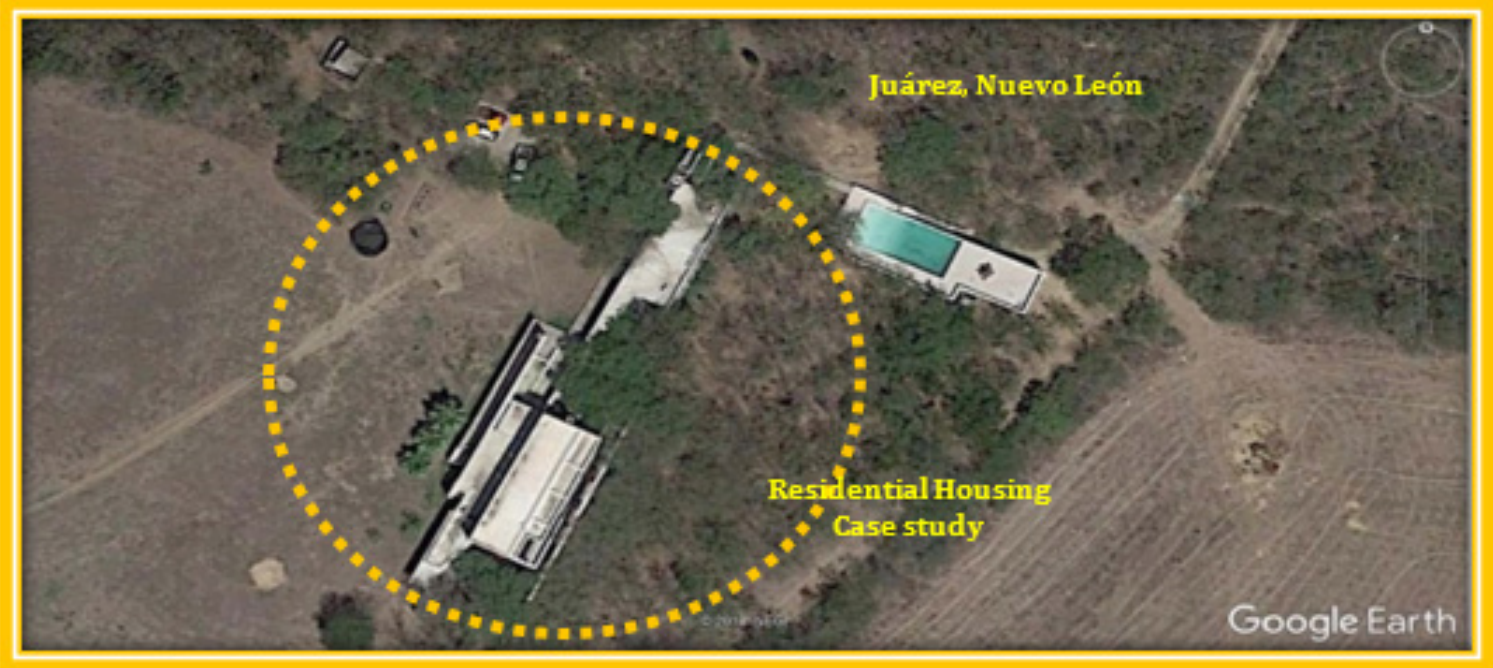

Figure 2: Location of passive residential housing case study. 


\section{Civil Engineering Research Journal}

Based on the urban and growth analysis of the State of Nuevo León, it is determined that the study area for residential housing is suburban-rural, as it is presented in the study area in the Municipality of Juarez, Nuevo León (Figure 2).

\section{Thermal Measurement Instruments}

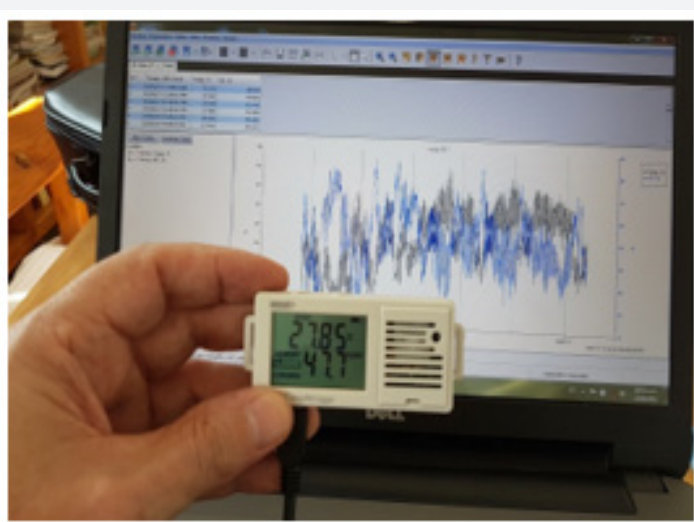

Figure 3: HOBO data logger UX100-003 of interiors.

The measurements are made with the data loggers, also called hobo's UX100-003. Team that is counted in the beginning of the investigation. The hobo is an electronic instrument capable of measuring the air temperature and humidity inside the residential housing case study, (Figure 3), the 24 hours of the day.
There's also the HOBO U23 Pro v², Onset brand (Figure 4) for the outdoor temperature of the residential home. Lantitsou \& Panagiotakis [4] express that they must be placed at a considerable height -at least four meters high- during a year and detail the critical months of temperature which, in this case, is August for summer and January for winter of 2018.

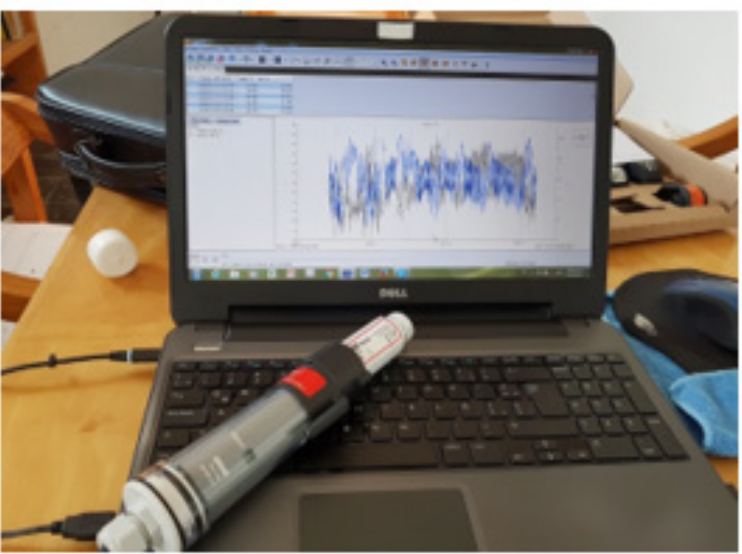

Figure 4: HOBO U23 Pro v2 of inclement weather.

\section{Discussion}

According to the National Oceanic and Atmospheric Administration of the United States (NOAA) and the National Aeronautics and Space Administration (NASA), the month of August 2018 was the hottest recorded in history; they underscored the extremely worrisome trend of the record global average temperature, which is becoming more and more frequent. Recent years have witnessed growing concern about the impact of climate change on housing outcomes, in terms of internal thermal comfort and the energy consumption needed to safeguard said comfort.

It is not an exaggeration for Vaccari et al. [5] to say that humanity now faces the most serious threat of its existence. This is a planetary emergency and a complete response if you wish to have any hope of avoiding the impacts of climate change, dangerous and irreversible. In relation to the thermal behavior of residential housing, it was determined, by historical climate analysis, that in August it presents an oscillation -with an average temperature of $30.47^{\circ} \mathbf{C}$ - in the critical summer month. The linear trend of the last 25 years in the municipality of Juárez, Nuevo León is $0.48^{\circ} \mathrm{C}$. The -interior exhibits a lower average oscillation temperature of $30.76{ }^{\circ} \mathrm{C}$ to $31.33{ }^{\circ} \mathbf{C}$ - because it is in the upper floor. For being in greater contact with the walls and, mainly, the roof slab. The maximum thermal amplitude oscillates with respect to the outside temperature in the month of August is of $03.66^{\circ} \mathrm{C}$ and the minimum of $00.35^{\circ} \mathrm{C}$. In August, the difference + accumulates $59.3^{\circ} \mathrm{C}$ and the difference - is $54.35^{\circ} \mathrm{C}$ and in January the difference $+25.53{ }^{\circ} \mathrm{C}$ and the difference - is $3.78{ }^{\circ} \mathrm{C}$ therefore the residential housing case study presents high temperatures at 
interior throughout the year of 2018, which is when the research work is done. Exposing therefore, that it is a residential housing that requires artificial air conditioning both in summer and in winter with a considerable energy expenditure.

\section{Conclusion}

Finally, it is confirmed that for the constructive solutions adopted by the residential housing of the municipality of Juárez, Nuevo León, it doesn't have a positive thermal behavior. Outside, having lower temperatures than the interior of the housing case study, it is recommended to have greater ventilation with openings in the upper part so that, by convection, it is cooler and, thus, propose some more effective constructive elements of aeration to mitigate the accumulation of temperature.

It is recommended, as constructive elements, not to forget to remove and add accessories in the residential housing for the summer season such as awnings, screens, shutters, sliding doors, doors with manual mechanisms -to allow or prevent the entry of air-, adjustable windows in various positions and openings, eaves, canopies, grills, pergolas and vegetation.

\section{Acknowledgment}

In a formal way, I appreciate the deference for the support and authorization of the Framework Agreement for Academic

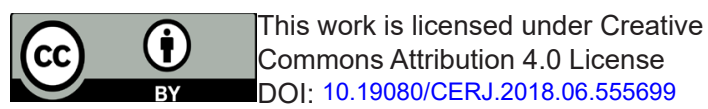

Cooperation of the Program for Professional Development, for the higher type subscribed by the General Directorate of Higher Education University with the Autonomous University of Tamaulipas (UAT) for the completion of the short research stay that I am currently carrying out in the Municipality of Juárez, Nuevo León (Official Letter NDSA / 511-6 / 18-6972).

\section{References}

1. Sodoudi S, Shahmohamadi P, Vollack K, Cubasch U, Che-Ani AI (2014) Mitigating the Urban Heat Island Effect in Megacity Tehran. Advances in Meteorology 2014(547974): 19.

2. Li Y, Babcock RW (2014) Green roofs against pollution and climate change. A review. Agronomy for Sustainable Development 34(4): 695705 .

3. Croitoru C, Nastase I, Sandu M, Lungu C (2016) Multi-criteria design and impact on energy consumption of a residential house- a parametric study. Energy Procedia 85(3): 141-148.

4. Lantitsou KI, Panagiotakis GD (2017) Thermal analysis of residencies based on solar design principles -a case study in Thessaloniki, Greece. Fresenius Environmental Bulletin 26(2): 1254-1262.

5. Vaccari FP, Gioli B, Toscano P, Perrone C (2013) Carbon dioxide balance assessment of the city of Florence (Italy), and implications for urban planning. Landscape and Urban Planning 120 (2): 138-146.

Your next submission with Juniper Publishers
will reach you the below assets
- Quality Editorial service
- Swift Peer Review
- Reprints availability
- E-prints Service
- Manuscript Podcast for convenient understanding
- Global attainment for your research
- Manuscript accessibility in different formats
( Pdf, E-pub, Full Text, Audio)
- Unceasing customer service
Track the below URL for one-step submission
https://juniperpublishers.com/online-submission.php

